Hall, S. and Winlow, S. (2014) 'The English Riots of 2011: Misreading the signs on the road to the society of enemies', in Pakes, F. and Pritchard, D. (eds.) Riot: Unrest and Protest on the Global Stage. Basingstoke: Palgrave Macmillan

\title{
The English Riots of 2011: Misreading the signs on the road to the society of enemies
}

Steve Hall

Simon Winlow

Social Futures Institute, Teesside University, UK

Most of the riots that occurred in England throughout modernity were associated with symbolic protests and fuelled by an underlying sense of injustice about specific, objective grievances related to the position of the agrarian or industrial working classes in the socioeconomic and political structure. In the period that stretched from the $1880 \mathrm{~s}$ to the 1930s, however, it is possible to discern a significant shift in form. Perhaps the most important aspect of this shift was the gradual emergence and development of coherent, unifying political discourses amongst the popular classes (Thompson, 1991). To be specific, the motivation and symbolism that underpinned both protests and riots became increasingly shaped by the related but competing political visions of communism, socialism or Labourite social democracy. These discourses did not incorporate populations en masse, and indeed many individuals remained apolitical or conservative in outlook despite their continued economic exploitation and political marginalization. However, the influence exerted by these discourses was most certainly on the rise and, between the two World Wars, it could be seen at the forefront of most protests and riots.

The basic shape of the developmental curve is worthy of brief investigation. In the eighteenth and early nineteenth century protests and riots tended to be focused on specific concrete issues, such as taxes, food prices, alcohol control, religious rights, land rights, imports undercutting prices and mechanization of the production process and subsequent job losses (Rudé, 1963). Although ethical discourses loomed large, there was little sense of an underlying political discourse that could 'join the dots' and locate these issues and others like them in an overall political and socioeconomic system. However, in the first half of the nineteenth century, from 1819 'Peterloo' riots near Manchester, it becomes possible to 
discern the beginnings of the political complexity and motivational drive that would characterise future protests. This developmental process was framed in a growing awareness of capitalism's socioeconomic structure and exclusionary politics as mainstays of an interconnected system with a dynamic logic (Thompson, 1991). However, this awareness did not instantly permeate the popular classes to produce a coherent political response. As Priestland (2012) has recently argued, the latent underlying class struggle was superimposed and in many respects overwhelmed by the cultural politics of an internal 'caste struggle' between aristocratic landowners, merchants represented by the free trade movement, and idealistic bourgeois social liberals, Chartists, Utopian socialists and so on. In England, even in the later nineteenth century, revolutionary Marxists were rather thin on the ground.

Despite this usurpation, the air in the nineteenth century crackled with the energy of political reform. It had become obvious to the more honest commentators that capitalism had replaced the relatively poorer yet far more stable agrarian way of life with an unstable market-driven economic system that was prone to periodic crash and recession (Hobsbawm, 1963). During these periods of crisis the underlying class struggle tended to emerge in very sharp relief for all to experience and symbolise, which presented a grave danger to the partnership of landed aristocrats and merchant-industrialists that constituted the ruling class. Many of the riots and protests were associated with unemployment and impoverishment. In 1886, in the midst of the severe Long Depression of 1873-1896, the relatively spectacular West End riots represented the complex tensions of the new English political dialectic. The riots were triggered by a demonstration by the Fair Trade League and a counter-demonstration by the new Marxist-inspired Social Democratic Federation, Britain's first organised socialist party, led by Henry Hyndman (see Bevir, 2011). The symbolism was quite clear and directly related to the primary dialectic tension that configured political economy; the bourgeois support for free trade and marketisation was pitted in direct conflict with the protectionism and cooperative industry demanded by the new representatives of the industrial working class, who claimed that the contradictions inherent in free trade and the unregulated marketization of the economy were behind a recession predicated on unemployment and a reduction in domestic demand. Despite this early influence, English socialism as it developed became heavily influenced by unorthodox Christian movements and middle-class social liberalism (see Chase, 2007). Thus it eventually resisted and marginalised Marxism, and there was to be no revolutionary struggle. 
The frequency of riots and protests declined in the early and mid-twentieth century. Those we did see, such as the General Strike in 1926, were by this time far more articulate and directly related to class politics (see Laybourn, 1993 for a full discussion). The general decline of riots and protests is correlated with the rise of institutionalised opposition. The rise of the Labour Party and the Trades Union movement, supplemented by various fringe Socialist groups catering for more stringent political demands, was indicative of the gradual institutionalisation of class struggle (Dahrendorf, 1969; Sassoon, 1997), which was then and some argue still is - the primary socioeconomic conflict in the capitalist system. This institutionalisation process allowed conflict to be articulated, symbolised, and sublimated to construct a long-running dialogue of inter-class negotiation, often tense and barbed but very rarely manifested in street protests, riots or physical violence. Social conflict, however, was always more complex and multi-layered than the basic class struggle (see Skeggs, 2004). The Women's Suffrage movement staged a number of protests in the early twentieth century, and, after the rise of fascism and Nazism after the First World War, England saw a number of antifascist protests, some of which, such as Cable Street in 1936, became quite riotous (see Wingerden, 1999; Kushner and Valman, 1998). However, from the General Strike in 1926 to the Jarrow March in 1936, most political demonstrations were relatively peaceful. The recognition, institutionalisation and articulation of primary social conflicts seem to correlate with peaceful protests and a healthy if rather protracted and partial progressive momentum (see Wieviorka 2009; Winlow and Hall, 2003).

It was this progressive momentum that characterised the post-war settlement during the period 1945 to 1979 . Aided by an increased emphasis on human rights as the world reflected on the horrors of Nazism, Stalinism and the Second World War, social conflict was institutionalised and intersectional ethico-social conflicts based around ethnicity, gender, and sexual relations were gradually recognised, articulated and incorporated into the institutional arrangement. The riotous protest was transformed into the peaceful, organised demonstration, which became the norm in the post-war period up to 1981. In the 1950s immigration, racism and ethnic tensions were behind some riots, but the rather accelerated recognition and institutionalisation of this social conflict gradually defused the situation. Tension persisted, individual acts of racial violence still occurred and fringe fascist parties arranged demonstrations, but serious violence was largely avoided as legislation and anti-racist cultural forces slowly began to change perceptions and impact on the structural tension in race relations. 
However, just as some level of success was achieved in the social democratic era, in the 1970s we entered the era of 'late' or 'advanced' capitalism. In economic terms this was characterised by the arrival of a long recession in the West, and in political terms by the revival of classical economic liberalism in the guise of neoliberalism. This new political movement, dubbed the 'Restoration' by Alain Badiou (2007, 2010), was represented in England by the Tory government elected in 1979, nominally conservative but in its philosophy and practice a tense combination of cultural conservatism, individual libertarianism and economic liberalism. In the 1980s Tory Prime Minister Margaret Thatcher's deindustrialisation policy, an aspect of a US-led neoliberal economic macrostrategy of reversing the global flows of trade and capital in an effort to restore growth and profitability (see Varoufakis, 2011), destroyed the heavy industrial base of the British economy. Although some areas in the South-East of England prospered, the old heavy industrial and manufacturing zones in the North suffered badly, along with similar regions in Wales, Scotland and Northern Ireland. One of the deleterious results was a 'crime explosion' as criminal markets expanded in the de-industrializing zones (Reiner, 2007; Hall et al, 2008). Under neoliberal governance supported culturally by the mass media's relentless broadcasting of the TINA ("there is no alternative") doctrine, politics became truncated and compressed in the centre-right sector and the British parliamentary political system lost even the restrained oppositional stance once represented by the left wing of the Labour Party.

From the 1980 s a potent depoliticising current ran through the population as the majority were rapidly incorporated into the seductive spectacle of consumer culture (Hall et al, 2008). The British state buckled under the authority of the large corporations and banks as all nations became ensnared in the stringent logic of a globalising capitalist market (Judt, 2010; 2011). The supine and heavily policed liberal intellectual establishment, under the influence of thinkers such as Derrida, Foucault and Giddens, jumped at the opportunity to abandon the class struggle and plunge us all into the fragmentary, divisive world of lifestyle, gender and identity politics, whose advocates ranged across a broad spectrum from multicultural tolerance and reconciliation to hostile separatism (see Winlow, 2012). For some of these new left-liberal thinkers, race and gender replaced class as the fundamental socio-structural relations of inequality (see Žižek, 2002). Amidst a dwindling number of protests, the category of socioeconomic class, already deracinated and turned into a politically inert occupational classificatory order by Weberian stratification theorists using a rigid and undialectical 
geological metaphor, was marginalised in the liberal-dominated intellectual and political establishment. Some former leftists, such as Young (1999), took the opportunity to suggest with no great subtlety that the decline of a working class that still contained currents of racism and sexism was perhaps no bad thing. It was a bad time to be a member of the working class. Genuinely sophisticated analyses of the intersection of race, class and gender as well as culture and socioeconomic positions did not begin to reappear until quite recently (see Skeggs, ibid.).

After the National Union of Mineworkers was betrayed by an increasingly fragmented Trades Union Congress and subsequently defeated in the Miner's Strike in 1985, the English working class virtually disintegrated as a latent collective political force, a potential class for itself (Marx and Engels, 2004 [1848]). As Eastern European state socialism and the Soviet Union disintegrated in the early 1990s, Francis Fukuyama (1993) proclaimed the 'end of history' and the ultimate triumph of liberal capitalism. The TINA doctrine looked to have won the day, and the majority adapted to its unforgiving demands with a shrug of the shoulders; "it's corrupt and exploitative, but it's better than totalitarianism", muttered the almost silent majority. Both Marx and Engels (ibid.) and Bauman (2000) were wrong: the modernist tradition and its agents neither melted into air nor liquefied; they turned to dust and lay in an inert heap on the ground staring upwards into the consumer spectacle's giant movie screen. In the 1980s the working-class project of recognising mutual interests, constructing coherent, unifying political symbolism and seeking political representation also disintegrated in the wake of heavy political defeats and the triumph of neoliberal ideology. In an electoral democracy there was no longer anything solid enough to offer the coherent alternative vision that would have been necessary to inspire mass resistance against the shift to neoliberalism, and therefore the shift was abrupt and its effects were quite spectacularly destructive. The economic heart was ripped out of numerous industrial regions and urban centres (Winlow, 2001), the 'solidarity project' was abandoned, competitive individualism reappeared in intense forms, long-term unemployment and family breakdown increased and criminal markets - especially drugs - burgeoned (Reiner, 2007; Hall et al, 2008). Ill fared the land.

The neoliberal realignment and the ensuing socioeconomic destruction that characterised the 1980s triggered a number of riots in economically disadvantaged areas - following a smaller riot in Bristol in 1980, in 1981 larger riots erupted in Brixton in London, Toxteth in Liverpool, Handsworth in Birmingham and Chapeltown in Leeds. Smaller skirmishes 
appeared in many economically deprived areas throughout the decade, but in 1985, closely following a smaller riot occurring yet again in Brixton, a major riot erupted in the Broadwater Farm area of North London; a black resident was shot by police during a house search and a policeman was also killed by rioters wielding machetes and knives, the first policeman to be killed in an English riot since 1833 (see Lea and Young, 1993). In the same year a second major riot also erupted in Handsworth. Individual riots are always quite complex affairs, but throughout the decade this normal aetiological complexity was overridden by two major common factors: long-running racial tension between black residents and the police and longterm socioeconomic deprivation in which criminal markets had burgeoned. The symbolism of comprehensible protests against racism, injustice and deprivation permeated the riots and the political discourse that lingered throughout the decade. The riots followed the tradition of protest with an object, but what had changed was the marginalisation of the sort of heavy undercurrent of named and institutionalised visionary political symbolism - communism, socialism, social democracy - that had to varying degrees played a fundamental role in the riots of the late nineteenth and early twentieth centuries, and which had been both the trigger and purpose of some, such as the West End riots of 1886. The riots in the 1980s were against various injustices, but, unlike the Miner's Strike, which was strongly associated with socialist politics, for nothing that could be ascribed even the vaguest political name.

Occasional riots and protests continued into the 1990s. In 1990 the Poll Tax Riots that occurred across the nation were most emphatically against the Poll Tax, but, amongst the majority of participants, again for nothing in particular apart from perhaps the broadest abstraction of socioeconomic justice. It is perhaps telling that, despite the organisation of initial protests by the Militant-led All Britain Anti-Poll Tax Federation, the larger riots that followed were associated with an individualist agenda; the Poll Tax would have hit individuals in their pockets, so amongst the majority it was difficult to discern a collectivist political agenda apart from a vague anti-Thatcherism. We might suspect that this individualist agenda was necessary to provoke action from the majority. Those who carried forward the positive political agenda of the original organising body were quickly confined to the fringes of what they might have regarded as their own protest and, as usual, their presence was misrepresented by the press as opportunistic political entryism and troublemaking. Leftist factions blamed each other for the violence and vandalism that flared up, but all including the usual suspects, the Anarchists, were cleared in later police reports. The most feasible 
explanation is that most of the violence was the product of random individuals and groups taking advantage of the cover given by large crowds and hard-pressed policing.

Throughout the 1990s and 2000s protests and riots tended to take three major forms. Firstly, riots triggered by hostility felt towards the police, such as the Meadowell-Elswick riots in 1991 in Newcastle upon Tyne and the Brixton riots in 1995, the former triggered by insults thrown by police at young offenders and the latter by the death of a black man in police custody. Secondly, the country saw riots triggered by the racial tension that had built up in the late $20^{\text {th }}$ century, such as those in Oldham, Leeds, Bradford and Burnley in 2001 (see Webster, 2003; 2012). These two forms, however, share a common context insofar as they occurred in areas of deindustrialisation, economic insecurity and relative deprivation. Smaller-scale riots also emerged from politically-inspired protests, but the temporal pattern of this form is interesting. In 1993 the Welling riots occurred amid political protests organised by the Socialist Workers Party and the Militant Tendency, both of whom had clear, articulate political visions of the sort that inspired the Social Democratic Federation in the 1880s, although the riots of 1888 were on a far larger scale. As we move into the 2000 s, however, we can see a shift in the form of political protests and riots. The Carnival Against Capitalism in 1999, the May Day riots in 2000 and 2001, the G-20 summit protests in 2009, the UK student protests against increases in fees and public sector cuts in 2010 and the anti-cuts protest in London against government public spending cuts in 2011 were all characterised by some rioting, but the positive, articulate political vision had virtually disappeared and the negative protest that to some extent characterises and often triggers riots had monopolised each event as a whole. The protests staged by the international Occupy movement in 20112012 were quite vociferously against banking malfeasance, corrupt politics and austerity measures, but, if we define politics as the means by which socioeconomic systems are organised to benefit all, they had no coherent, alternative political programme to offer (Winlow and Hall, 2012a). The pattern of the shift across these two decades was from a mixture of negative and positive protests to purely negative protests. The articulate political symbolism had virtually disappeared. Perhaps Slavoj Žižek (2011) is right that history has not ended, but the majority, whose motivations are restrained by an unconscious acceptance of neoliberal ideology and the TINA doctrine, now act as if it has. The shifting nature of protest and riots suggests that over the past 200 years we have travelled from an era of pre-political negativity through an era of political positivity to enter a post-political interregnum characterised by a disavowed capitulation to neoliberalism. 
At a higher level of abstraction we can distinguish three major strands in the mutation of politics as indicated by the shifting nature of riots and protest. From a pre-political era where the majority were largely excluded from the political process we moved through, firstly, an era of objectification, complexity and abstraction in the $19^{\text {th }}$ century to, secondly, a political heyday of unification through abstraction in the first half of the twentieth century. After this 'politics of the Real' (see Badiou, 2002) collapsed into the horrors of the Gulags, the Cultural Revolution and the Killing Fields, the English - since the seventeenth century quite averse to such extreme militancy and revolutionary fervour - along with most of Western Europe developed pacified, institutionalised systems of political negotiation over fundamental socioeconomic and cultural conflicts during the era of the post-war settlement (Wieviorka, 2009). The class struggle did not disappear in England, but it was conducted in an environment of compromise and negotiation, with at least some recognition of mutual interests across the social structure.

Thirdly, however, the ideological and political triumph of neoliberalism between 1980 and 2008 propelled England and most of the West into a post-political era (see Žižek, 2008). The defeat of militant political organisations such as the NUM and the witnessing of the spectacular collapse of the economically stagnant and politically corrupt Soviet Union and its satellite states turned public opinion away from the traditional socialist alternative. Social democratic control of the global capitalist economy - based on Keynesian exchange controls, fiscal stimulus and demand management - was lost as neoliberals dismantled the interventionist political apparatus on which it depended. As liberal-postmodernism achieved popularity it launched a philosophical attack on the very principle of unifying abstraction, which further weakened the defences against triumphant neoliberalism; the jury is still out on whether this was a deliberate capitulation based on cynical and pragmatic 'least-worst' calculation or an unwitting political disaster (see Badiou, 2002; Žižek, 2011). Universal symbolism, dialectical class struggle and the 'passion for the real' (Badiou, 2002) were abandoned in favour of pluralistic identity politics, autonomous social movements and single issue politics. Strikes diminished and union membership decreased (see Thomsen, 1997). To the chagrin of more radical thinkers, the Fabian centre-left liberals who dominate English political science, philosophy and the social sciences carried on as if nothing major had happened, as if the return of a few decent politicians in the Parliamentary system to implement few decent policies will stabilise the tectonic socioeconomic shifts we are all 
currently experiencing and arrange the 'inclusion' of those being cast out of the system at an alarming rate.

The triumph of ideology in popular culture has been quite remarkable (Winlow and Hall, $2012 \mathrm{~b}$ ). It went hand-in-hand with the incorporation of the majority of the population into the surrogate world of consumer culture, where individuals now compete against each other to acquire and display symbols of social distinction carried by consumer goods. Liberal-left and postmodernist academics once saw consumer culture as a site for free identity-creation, new communities and resistance against the norm (see for example Featherstone, 2007), but this rather naïve view, born of capitulation and compromise amid neoliberal triumph, is now coming under increasing attack (see Heath and Potter, 2006; Hall et al, 2008; Smart, 2010). What we can see clearly as a major pattern across the past thirty years is the destruction of the unifying political institutions and symbolism once either embraced or at least considered worthy of attention by the majority of the population and their concomitant incorporation into consumer culture as the two main strands of an overall project aimed at once again removing the mass from the political sphere. The gradual depoliticisation of protests and riots are a major indicator of this process.

So, put simply, in broad terms the typological pattern of riots in England since the early nineteenth century follows the rise, institutionalisation, deinstitutionalisation and fall of unifying political symbolism. The bulk of thinkers in the broad liberal-postmodernist school tend to argue that what followed the decline of unifying political symbolism was a complex, fragmented yet ultimately progressive realm of identity politics operating in the liberated spaces created by consumer capitalism (Featherstone, 2007; Lash, 2010). Most tend to avoid the more critical analysis: that unifying politics was systematically dismantled by a combination of neoliberal and liberal-postmodernist forces whose agents had decided that managed global capitalism attended by a culturally fragmented and highly individualised post-social realm was the safer option; no more dialectical conflicts and struggles, no more rebellions, no more violence (Hall, 2012a). Even more assiduously avoided was the sophisticated and well-rehearsed critique of consumerism - drawn from eclectic intellectual sources across the traditional political spectrum from conservative romanticism to MarxistFreudianism - that consumer culture was a depoliticising trap that captured libidinal drives and desires in order to distract them from politics and the transcendental ideals that nourished the political imagination and incited political action (see Hall et al, 2008; Stiegler, 2010). The 
sheer theoretical narrowness and superficiality of the politically truncated Weberian and liberal-postmodernist sociology that has been dominant since the 1980s is one of its most striking features, and we have to ask whether it is, in its current form, able to supply us with the concepts and critical depth we need to analyse today's social phenomena. Criminological theory, beholden to this currently restrictive form of sociology and fixated on its own longrunning critique of external systems of control - with few alternative positions to draw upon apart from conservative-administrative positivism - appears to be in an even weaker condition.

However, thinkers from other disciplines such as philosophy, cultural studies, politics and humanities, along with the anarchic denizens of the blogosphere, seem to operate with significantly less restriction. As soon as the English riots of August 2011 hit the news headlines they were dubbed 'the consumer riots', 'the riots at the end of history' and so on. There was good reason for this. Early attempts by researchers to uncover proto-political resistance and the struggle for justice as the main drives for the riots were unconvincing (Treadwell et al, 2012). The riots began as a small protest in Tottenham, London, against the shooting of an alleged criminal, Mark Duggan, by metropolitan police officers. However, as rioting spread across London and other large metropolitan areas of England, including Manchester and Birmingham, the initial protest against injustice seemed to disappear into the background. The riots did not evolve into a broader protest that displayed any articulate, coherent or unifying political symbolism. In fact there was no political symbolism at all in the traditional sense of the term, and none of the usual involvement by fringe political groups. The initial object disappeared very quickly, no political symbolism appeared and the riots rapidly degenerated into what can only be described as aggravated shopping. Of course, they occurred in areas of socioeconomic deprivation, and the Coalition government's austerity cuts were making conditions worse, but, despite this, the only way to describe the riots as in any way 'political' would be to redefine the term itself beyond its limits.

It would also be to fly in the face of the evidence. As we have said, early research studies were unsatisfactory and the ascription of even inarticulate underlying political motivations is hasty and quite dubious. The experienced ethnographers working in our research team, Daniel Briggs and James Treadwell, situated in London and Birmingham respectively, headed onto the streets to collect data from active rioters during the riots, and over the following weeks followed up this initial sweep with a number of in-depth semi-structured 
interviews with participants in the riots. The data gathered during the heat of the moment, backed up by data gathered later from respondents who had entered into relations of trust with the researchers and volunteered for lengthy interviews, were stark indications of the relative ineffectiveness of the earlier voxpop-style interviews conducted by the joint LSE/Guardian researchers. This data has already been published (see Treadwell et al, 2012), but, to sum up, both sets indicate very strongly that the rioters' primary concern was not to exact revenge on police and the government, or broadcast some political message or even specific complaints about life on the socioeconomic margins. For us it would have been perfectly understandable and legitimate - in fact heartening and inspiring - if they had; but they did not. The most common motivation for participation in the riots and their brief, limited but nonetheless spectacular diffusion was that those initially looking on became envious of others who had taken the early initiative to loot desirable designer goods - clothes, watches, jewellery, electronic gadgets and so on - and on the spur of the moment decided to join in. The 'buzz', so often associated without a great deal of reflection by criminologists to some suppositious 'natural' urge to defy 'authority' (see Katz, 1990), was, according to this data, inextricably linked to the acquisition of goods. Even those who stole to sell on expressed the wish to use the money to buy similar objects in an upmarket store, adding the 'shopping experience' to the symbolism of the objects themselves. These riots occurred during a phase of advanced capitalist history in which the total lack of coherent class politics and alternative sources of identity has left the majority of young people with no choice but to seek identity, status and respect by acquiring the post-social, post-political symbolism that has been attached to consumer objects by the marketing industry.

It is a rather sobering thought that many of our respondents could not name Mark Duggan or describe how he was killed. Very few talked about the withdrawal of welfare services or any government policy. All those taking part failed entirely to deliver an articulate ethical or political message associated with their socioeconomic plight or the politics of the day. No outrage was directed towards corrupt elites and the political and ideological agents of the exploitative neoliberal capitalist system. They appeared in the interviews and in their observable actions as individuals without a history, without a future and without an identity outside consumer symbolism. With the forces of law and order temporarily caught on the back foot, the riots carved out a space for the 'acting out' of deep political impulses (see Stiegler, 2009), but nothing happened at all except a bout of frenetic shopping; there was no transgression of any aspect of the liberal-capitalist order apart from the law, only hyper- 
conformity to the drives captured and energised by consumer culture. No trace of the symbolically efficient collectives, the institutions of conflict or the articulate political statements that had become working-class norms in the heyday of industrial capitalism and high modernity could be found.

The interviewees' statements and demeanour were shot through with resignation, cynicism, pragmatism and the depressive hedonia described by Mark Fisher (2009) in his encounters with FE students. There was no faith in today's politics or politicians, only the constant expression of 'capitalist realism' (ibid.), the new postmodern function of ideology, which attempts to retain the gap between conscious knowledge and the unconscious drives and desires that incite social action. This was working-class - and we must stress that we use this term only in the sense of a class in itself and not a class for itself - youth culture amid the decline of 'symbolic efficiency' and collective political narratives, the total disappearance of the inspiring political symbolism that could represent an alternative socioeconomic system (Winlow and Hall, 2012a; see also Žižek, 1995; 2008; 2011). This is the era of the total triumph of neoliberal ideology amongst the English masses, where, in the battle to win hearts and minds, mass-mediated consumer culture has won hands down as the left threw in the towel. This is now the default position, the context in which all social action takes place.

The failure of the Occupy movement and other organised protests in the USA, Britain and mainland Europe to garner mass support despite their accurate identification of the object of ethical critique can also be attributed to the absence of a coherent alternative ideology based on a plausible means of reorganising the global economy. The middle class, hyper-alienated from the working class across a huge chasm of differentiated cultural and symbolic capital, can no longer inspire the latter by constructing the potent symbolism that was once their 'caste speciality' (see Priestland, 2012). Nor, for that matter, can they inspire themselves; their protests were shot through with appeals to justice and parliamentary liberalism, which betrayed a naïve belief in the parliamentary democracy and reformism that has palpably failed to deliver social justice or change course even after the recent financial crash. Even the traditionally symbolically rich and sophisticated middle class offered no articulate vision; they were against everything but for nothing apart from vague abstractions kept alive by elaborate yet insubstantial rhetoric. 
Traditional liberal-left social science and politics, trapped in an obsolete intellectual framework from a superseded era where economic stability and political militancy provided an organic contextual platform, entirely lack the conceptual armoury required to analyse the phenomena appearing in the midst of the current economic turmoil or to help to reconstruct a new positive politics. The canon of old post-war texts in sociology and criminology is now largely obsolete, an 'undead' presence that, although resolutely kept moving to dominate intellectual space by agents who refuse to admit its demise, possesses no internal vitality of its own, and certainly no political function beyond cheerleader for Fabian welfarism. The disciplines continue to operate with obsolete concepts - resistance, moral panic, culture of control and so on (see Hall, 2012a) - and obsolete notions of ideology and subjectivity. Social science in general is an incestuous, narrow, self-referential, exhausted and hierarchal institution that allows established ideas all the space they need to defend themselves and steadfastly refuses to construct, import and utilise new concepts suitable for the analysis of today's social world. Those who do produce potent and relevant ideas, such as Bauman (2000 passim) and others, tend to have their ideas diluted or marginalised in favour of traditional Weberian faire or the anodyne products of an undead postmodernist regime discredited in the 1990s by the cutting edge of Continental philosophy (see for example, Žižek, 2002; Badiou, 2002).

In its refusal to adopt new ideas, to cut its ties with Fabian reformism, liberal-left politics and the doctrine that human beings in late capitalism are still driven by values, and to look upon the world from an unflinchingly realistic perspective, social science is incapable of conceptualising the socioeconomic context in which social life is to be played out in the coming decades. Since 1800 the capitalist economy has grown thirty-two times, a huge exponential spurt across a relatively short period of time. After 1945, Western nations called upon consumer culture as a 'new religion' (see Lebow, 1955) to ensure the continuation of demand-driven economic growth and prevent the collapse that led to the Great Crash of 1929, the Great Depression, the rise of Nazism and the Second World War. The following statement is invariably dismissed as 'reductionist' by liberals who seek only to avoid the issue of deep political intervention in the socioeconomic system because they fear the return of barbaric totalitarianism more than barbaric chaos, but it needs to be made and repeated often: consumer culture captured the drives of the masses in the post-war era, distracted them from their own politics and made their identity and happiness dependent on the acquisition of its symbolic objects. Depriving consumer subjects of their objects generates 
hostility, resentment and apolitical unrest; this, in the absence of unifying political symbolism, does not lead to the continuous dissent and transgression hoped for by liberalpostmodernists but to an atomised and resentful 'society of enemies' (Hall, 2012b).

As the capitalist economy enters a new phase in history where its past high level of growth becomes impossible (Heinberg, 2011; Harvey, 2011), the neo-feudal socioeconomic structure is polarising even further and economic participation and status - even subsistence for those in the Global South - cannot be guaranteed for the bulk of an expanding population. Further serious unrest and an increasing migration into low-level, normalised and largely undetected criminality is likely (see Hall et al, 2008) alongside the continuation and probable expansion and intensification of the systems of surveillance and social control operated by neoliberal states. This is not a 'prediction'; in many pockets across the globe this is happening right now (Žižek, 2011; Hall, 2012c). The only question is how far and how rapidly it might spread as global growth moves deeper into its uneven slowdown. Unless social science - already caught with its trousers down once as it offered virtually no response to the financial crisis in 2008 (Chakrabortty, 2012) - accepts that fundamental context it will lag quite considerably behind the pace of real processes and events and be unable to contribute to the intellectual and political renewal required to avert a slow-motion disaster.

Steve Hall is Professor of Criminology at Teesside University. In the 1970s he was a nomadic musician, general labourer and avid reader of anything political or philosophical. In the 1980s he worked with young offenders in the de-industrialising North-East of England, and he was politically active during the steelworks and mine closures in Co. Durham. In the 1990s he began teaching, researching and publishing. Essentially a criminologist, he has also published in the fields of history and philosophy. He is author of Theorizing Crime and Deviance (Sage, 2012), co-author of Criminal Identities and Consumer Culture (Routledge, 2008) and Violent Night (Berg, 2006), and co-editor of New Directions in Criminology (Routledge, 2012).

Simon Winlow is Professor of Criminology at Teesside University. He is the author of Badfellas: Crime, Tradition and New Masculinities (Berg, 2001), co-author of Bouncers: Violence and Governance in the Night-time Economy (Oxford University Press, 2003), 
Violent Night: Urban Leisure and Contemporary Culture (Berg, 2006) and Criminal Identities and Consumer Culture: Crime, Exclusion and the New Culture of Narcissism (Willan/Routledge, 2008). He is also the co-editor of New Directions in Criminological Theory (Routledge, 2012) and New Directions in Crime and Deviancy (Routledge, 2012).

Badiou, A. (2002) Ethics, London: Verso

Badiou, A. (2007) The Century, Oxford: Polity Press

Badiou, A. (2010) The Meaning of Sarkozy, London: Verso

Bauman, Z. (2000) Liquid Modernity, Oxford: Polity Press

Bevir, M. (2011) The Making of British Socialism, Princeton, NJ: Princeton University Press

Chakrabortty, A. (2012) 'Economics has failed us: but where are the fresh voices?', The Guardian, $16^{\text {th }}$ April 2012

Chase, M. (2007) Chartism: A New History, Manchester: Manchester University Press

Dahrendorf, R. (1969) Class and Class Conflict in Industrial Society, London: Routledge \& Kegan Paul

Featherstone, M. (2007) Consumer Culture and Postmodernism, London: Sage

Fisher, M. (2009) Capitalist Realism, London: Zero

Fletcher, A. (1985) Order and Disorder in Early Modern England, Cambridge: Cambridge University Press

Fukuyama, F. (1993) The End of History and the Last Man, London: Harper Perennial Hall, S. (2012a) Theorizing Crime and Deviance: A New Perspective, London: Sage Hall, S. (2012b) 'Consumer Culture and the Meaning of the Urban Riots in England', in Hall, S. and Winlow, S. (eds.) New Directions in Criminological Theory. London: Routledge 
Hall, S. (2012c) 'Don't Look Up, Don't Look Down: Liberal criminology's fear of the supreme and the subterranean', Crime, Media, Culture: Special Issue: York Deviancy Conference 2011, 8(2): 197-212

Hall, S. and Winlow, S. (2003) 'Rehabilitating Leviathan: Reflections on the state, economic regulation and violence reduction', Theoretical Criminology, 7(2): 139-162.

Hall, S., Winlow, S. and Ancrum, C. (2008) Criminal Identities and Consumer Culture:

Crime, Exclusion and the New Culture of Narcissism, Cullompton: Willan

Harvey, D. (2011) The Enigma of Capital, London: Profile Books

Heath, J. and Potter, A. (2006) The Rebel Sell, London: Capstone

Heinberg, R. (2011) The End of Growth, London: Clairview Books

Hobsbawm, E. (ed) (1968) Labouring Men, London: Weidenfeld and Nicolson

Judt, T. (2010) Postwar: A History of Europe since 1945, London: Vintage

Judt, T. (2011) Ill Fares the Land, London: Penguin

Katz, J. (1988) Seductions of Crime, New York: Basic Books

Kushner, A. and Valman, N. (1998) Remembering Cable Street: Fascism and Anti-fascism in British Society, London: Vallentine Mitchell

Lash, S. (2010) Intensive Culture, London: Sage

Laybourn, K. (1993) The General Strike of 1926, Manchester: Manchester University Press

Lea, J. and Young, J. (1993) What is to be done about Law and Order? London: Pluto Press

Lebow, V. (1955) 'Price Competition in 1955', Journal of Retailing, 31(1): 5-10, 42, 44

Priestland, D. (2012) Merchant, Soldier, Sage: A New History of Power, London: Allen Lane

Reiner, R. (2007) Law and Order: An Honest Citizen's Guide to Crime and Control, Oxford: Polity

Rudé, G. (1964) The Crowd in History: A Study of Popular Disturbances in France and England 1730 - 1848, New York: John Wiley

Sassoon, D. (1997) One Hundred Years of Socialism, London: Fontana 
Skeggs, B. (2004) Class, Self, Culture, London: Routledge

Smart, B. (2010) Consumer Society, London: Sage

Stiegler, B. (2009) Acting Out, Stanford, CA: Stanford University Press

Stiegler, B. (2010) For a New Critique of Political Economy, Oxford: Polity

Stiegler, B. (2011) The Decadence of Industrial Democracies - Volume 1, Oxford: Polity

Thompson, E.P (1991 [1963]) The Making of the English Working Class, London: Penguin

Thomsen, J.P.F. (1997) British Politics and Trade Unions in the 1980s, London: Dartmouth

Treadwell, J., Briggs, D., Winlow, S. and Hall, S. (2013) 'Shopocalypse Now: Consumer Culture and the English Riots of 2011', British Journal of Criminology, 53 (1): 1-17

Varoufakis, Y. (2011) The Global Minotaur: America, The True Origins of the Financial Crisis and the Future of the World Economy, London: Zed Books

Webster, C. (2003) 'Race, Space and Fear: imagined geographies of racism, crime, violence and disorder in Northern England', Capital and Class, May, 80: 95 - 122

Webster, C. (2012) 'Return of the Repressed? A Retrospective of Policing and Disorder 1981 - 2011' in S. Winlow and R. Atkinson (eds) New Directions in Crime and Deviancy, London: Routledge

van Wingerden, S. (1999) The Women's Suffrage Movement in Britain, 1866-1928, Basingstoke: Palgrave Macmillan

Wieviorka, M. (2009) Violence: A New Approach, London: Sage

Winlow, S. (2001) Badfellas: Crime, Tradition and New Masculinities, Oxford: Berg

Winlow, S. (2012) 'Is it OK to talk about Capitalism now? Or, Why Criminology must take a Leap of Faith', in S. Winlow and R. Atkinson (eds) New Directions in Crime and Deviancy, London: Routledge

Winlow, S. and Hall, S. (2012) 'A Predictably Obedient Riot: Postpolitics, Consumer Culture, and the English Riots of 2011', Cultural Politics, Volume 8, Number 3: 465-488 
Winlow, S. and Hall, S. (2012b) 'What is an 'Ethics Committee'? Academic Governance in an Epoch of Belief and Incredulity’ British Journal of Criminology, 52 (2): 400-416

Žižek, S. (1995) Tarrying with the Negative, Durham, USA: Duke University Press

Žižek, S. (2002) Did Someone Say Totalitarianism?: Four Interventions in the (Mis)Use of a Notion, London: Verso

Žižek, S. (2008) Violence, London: Verso

Žižek, S. (2011) Living in the End Times, London: Verso 